\title{
Economic Feasibility Analysis of the Industrial Production of Fish Protein Hydrolysates using Conceptual Process Simulation Software
}

\author{
Shan $\mathrm{He}^{1-3}$, Christopher MM Franco ${ }^{1-3}$ and Wei Zhang ${ }^{1-3 *}$
}

${ }^{1}$ Department of Medical Biotechnology, School of Medicine, Flinders University, Sturt Road, Bedford Park, SA 5042, Australia

${ }^{2}$ Flinders Center for Marine Bio-products Development (FCMBD), Flinders University, Sturt Road, Bedford Park, SA 5042, Australia

${ }^{3}$ Australian Seafood Cooperative Research Center, Box 26, Mark Oliphant Building, Science Park, Laffer Drive, Bedford Park, SA 5042, Adelaide, Australia

\begin{abstract}
The aim of this study was to analyze the economic feasibility of producing Fish Protein Hydrolysates (FPH) on an industrial scale using conceptual process simulation software, based on 3,900 tons of raw material, the maximum available annually in South Australia. The parameters of the microwave-intensified enzymatic process and the microwave-intensified chemical process, the two processes that we previously identified as the optimum to produce FPH with strong oil binding and emulsifying capacity, respectively, in laboratory-scale evaluations, were used to model a large scale simulation using Software Superpro Designer. The results of the simulation showed that the microwaveintensified chemical process is more profitable than the microwave-intensified enzymatic process when scaled up. The investment payback time and return on investment of the scaled up processes are both very sensitive to the purchase cost of raw material and selling price of fish protein hydrolysates. The food industry expects to get pay back on investment for producing FPH on an industrial scale in around 2 years. This study demonstrated that this aim is achievable by the combined contribution of the purchase cost of raw material (from USD $1 / \mathrm{kg}$ to USD $3 / \mathrm{kg}$ ) and the selling price of FPH (from USD 20/kg to USD 40/kg). As both these parameters can be realized we are able to show the profitability of producing FPH on an industrial production.
\end{abstract}

Keywords: Fish protein hydrolysates; Industrial production; Conceptual process simulation; Process simulation software

\section{Introduction}

Fish Protein Hydrolysates (FPH) is defined as fish proteins that are broken down into peptides of various sizes [1]. In comparison with intact fish protein, FPH demonstrated a variety of functions that can be applied in the food industry. The two major methods to produce FPH are enzymatic and chemical processes [2-5] optimized the processing conditions for the enzymatic process to produce FPH with high oil binding capacity and high emulsifying capacity, with a high protein recovery from Yellowtail Kingfish (YTK). Tri et al. used chemical processes to produce FPH; they produced FPH from salmon at $\mathrm{pH} 1,2,3$ and $121^{\circ} \mathrm{C}$ for $40 \mathrm{~min}$, and found the $\mathrm{FPH}$ produced at $\mathrm{pH}$ 3 was the best substrate to promote microbial growth of Lactobacillus for yoghurt production. Enzymatic and chemical processes have also been modified in order to achieve a better outcome. He et al. [1] used microwave intensification to improve both the enzymatic and the chemical processes, resulting in shorter production times and FPH with stronger oil binding and emulsifying capacity.

However as these production studies were limited to the laboratory scale the outcome has not been translated to industrial scale production by the food industry. In order for the results of the optimized production system, obtained at the laboratory scale, to be translated to an industry scale it is necessary to address the concerns of the food industry about investment payback time [2,3]. According to our survey, the food industry considers a reasonable payback time on investment into an industry scale FPH technology to be no more than 2 years. However, so far the economic feasibility of FPH production at an industrial scale has not been analyzed yet.

Process simulation software is a powerful tool for such an economic evaluation; which can be utilized to evaluate the process performance in silico before any expensive scale-up of production. These process simulators offer the opportunity to shorten the time required for industrial process development. They allow the comparison of process alternatives so that a large number of process designs can be synthesized and analyzed interactively in a short time. They computationally simulate the process to reduce the time necessary for the development and scale-up of a process; they also model and predict the production costs for an industrial scale production process [4-7].

The proprietary software package Superpro Designer was used to predict and quantify process and economic parameters. It was specifically developed for the biotechnology industry, which successfully overcomes the weakness of previously developed process simulation software for biotechnology processes. Bioprocesses often involve raw materials and products such as cells and proteins, whose exact physical properties or structure or chemical composition may not be fully known, thereby affecting the accuracy of the simulation outcome. The large data base of specific feed stocks and unit operations in Superpro Designer successfully increased the accuracy of the bioprocess simulation. It has been used to simulate many different types of biological processes at an industrial scale, such as production of $\beta$-galactosidase and molasses [6].

The objective of this study was to carry out an economic feasibility analysis of FPH production on industrial scale, in order to identify the total investment cost, operation cost, return on investment and the most

${ }^{*}$ Corresponding author: Wei Zhang, Medical Biotechnology, Flinders University, Level 4, Health Science Building, Bedford Park, 5042, Adelaide, South Australia Australia, Tel: +618-722-185-57; Fax: +618-722-185-55; E-mail: wei.zhang@ flinders.edu.au

Received December 04, 2014; Accepted January 21, 2015; Published January 26, 2015

Citation: Shan He, Christopher MM, Franco, Zhang W (2015) Economic Feasibility Analysis of the Industrial Production of Fish Protein Hydrolysates using Conceptual Process Simulation Software. J Bioprocess Biotech 5: 191 doi: 10.4172/2155-9821.1000191

Copyright: ( 2015 Shan He et al. This is an open-access article distributed unde the terms of the Creative Commons Attribution License, which permits unrestricted use, distribution, and reproduction in any medium, provided the original author and source are credited. 
Citation: Shan He, Christopher MM, Franco, Zhang W (2015) Economic Feasibility Analysis of the Industrial Production of Fish Protein Hydrolysates using Conceptual Process Simulation Software. J Bioprocess Biotech 5: 191 doi: 10.4172/2155-9821.1000191

Page 2 of 8

importantly, the investment payback time, by processing simulation using the software package Superpro Designer. Our previous study [5] has already defined that oil binding capacity and emulsifying capacity of FPH are two important functions for the food industry. It also compared different processes and found the microwave-intensified enzymatic process as the best process to produce FPH with strong oil binding capacity while the microwave-intensified chemical process as the best process to produce FPH with strong emulsifying capacity. These results provided the basis for the simulation to economically evaluate the optimum the industry scale production of FPH with either of these properties.

\section{Simulation Method}

\section{Process simulation description}

Our previous study determined that the microwave-intensified enzymatic process in $20 \mathrm{~min}$ using Flavourzyme (protein recovery of $65 \%)$ and the microwave-intensified chemical process (protein recovery of $98.05 \%$ ) in $20 \mathrm{~min}$ at $\mathrm{pH} 14$ are the most suitable to produce FPH with high oil binding capacity and the high emulsifying capacity, respectively [5]. It used the head and frame of YTK, which are Fish Processing Co-Products (FPCP), as the raw material to produce FPH due to their high content of fish muscle protein and low purchase cost. As the protein in the raw material cannot be fully used to produce $\mathrm{FPH}$, this previous study reported the FPH protein recovery of the microwave-intensified enzymatic process (61.45\%) and microwaveintensified chemical process $(98.05 \%)$. Simulations were based on the conceptual designs of these two processes on an industrial scale, and considered the South Australian annual available head and frame of YTK as the maximum amount of raw material.

\section{Simulation of the microwave-intensified enzymatic process}

The process design on industrial scale: The conceptual design of the industrial scale process is illustrated in Figure 1. The process parameters of each unit operation are based on results presented in our previous paper [5].
Assumptions for simulation: The simulation was based on three major assumptions: annual available FPCP, the purchase cost of FPCP and the selling price of the final products.

For annual available FPCP, our previous study [5] stated that about 5,000 tons of YTK FPCP was estimated to be produced in South Australia, the major source of YTK production in Australia. Our previous study also reported that head and frame account for about $65 \%$ of YTK FPCP. Therefore South Australia's annual production was $5,000 \times 65 \%=3,900$ tonnes of head and frame of YTK in 2012. The simulation was designed based on the assumption that 3,900 tonnes YTK head and frame as the starting raw material are the maximum amount available per year in South Australia.

For the purchase cost of FPCP, an investigation carried out showed that currently the seafood industry in South Australia offers FPCP at no cost to produce fertilizer, or pays USD 150 per tons for waste disposal. However, the seafood industry proposes to sell the FPCP at the price of USD $3 / \mathrm{kg}$, if FPCP is processed to FPH, due to the increased market value. Therefore, USD $3 / \mathrm{kg}$ was set as the purchase cost of FPCP $[8,9]$.

Prices of products were assumed at the current market prices of the same products, or similar products as references. FPH powder was defined as the main product/revenue stream; fish oil and the resultant FPCP left-over were defined as co-products/revenue in this simulated process. The price of fish oil was set at USD 1.2/ kg. The price of FPCP left-over was similar to that of fish meal, so the recent market price of fish meal (USD 1.7/kg) was used as reference. For FPH, our previous study [5] compared FPH with egg white powder, the commercial food grade oil binder and emulsifier, which has a reference price of USD 20/ $\operatorname{kg}[10]$.

Equipment selection: Based on the equipment used in the microwave-intensified enzymatic process on laboratory scale mentioned in our previous study [5], the equipment used in the simulation was selected from the equipment list of Superpro Designer. They include a grinder, microwave-intensified reactor or chemical reactor for hydrolyzation, centrifuge, storage tanks and a spray drier [11].

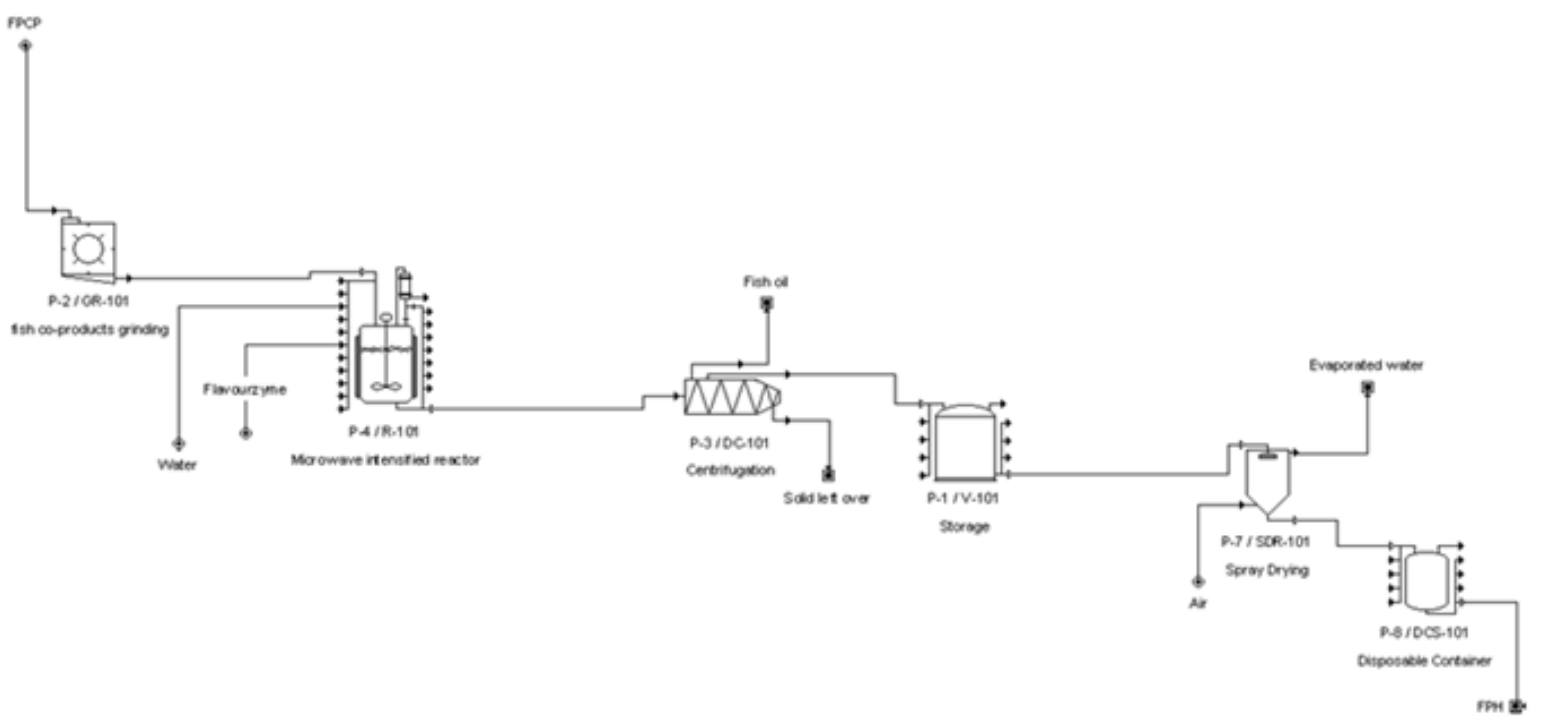

Figure 1: The flow sheet for the microwave-intensified enzymatic process to produce FPH 
Citation: Shan He, Christopher MM, Franco, Zhang W (2015) Economic Feasibility Analysis of the Industrial Production of Fish Protein Hydrolysates using Conceptual Process Simulation Software. J Bioprocess Biotech 5: 191 doi: 10.4172/2155-9821.1000191

Page 3 of 8

Equipment cost: The cost of equipment was automatically defined by Superpro Designer (version 8.0) with reference to the 2012 market price, by adjusting the specific volume or capacity. For example: the cost of a $1 \mathrm{~m}^{3}$ microwave-intensified reactor for hydrolyzation was USD 565,000, and the cost of a $10 \mathrm{~m}^{3}$ microwave-intensified reactor for hydrolyzation was USD 734,000; the cost of a spray drier with a drying capacity of $9000 \mathrm{~kg} / \mathrm{h}$ was USD 291,000, and the cost of a spray drier with a drying capacity of $12000 \mathrm{~kg} / \mathrm{h}$ was USD 307,000. The volume or capacity of equipment was chosen in relation to the production yield per batch.

Annual operation hours: The process operation mode was set up as a batch process. The annual operation time was set at $7200 \mathrm{hrs}$, the typical annual operation time for a batch process.

Key processing parameters: The annual amount of head and frame of YTK FPCP used was automatically calculated by Superpro Designer (version 8.0) based on different production yields per batch. The $\mathrm{FPH}$ production yield per batch was set at $100 \mathrm{~kg} / \mathrm{batch}$ as the lowest and increased $100 \mathrm{~kg}$ per simulation until the annual raw material consumed reached 3,900 tons, the maximum amount of raw material available in South Australia per year.

The protein recovery in the microwave-intensified reactor for hydrolyzation was set at $61.45 \%$ using the experimental data of the microwave-intensified enzymatic process in 20 min using Flavourzyme in our previous study [5]. The annual depreciation of equipment was automatically set at $10 \%$. The labor cost was automatically set at USD 69/hour, by the Superpro Designer, to reflect the Australian labor market $[12,13]$.

Centrifugation separated the hydrolyzed materials into three different streams: fish oil in the top stream, FPH solution in the middle stream and un-hydrolyzed FPCP as left-over at the bottom (Figure 1). The yield of each stream was set based on the extent of the reaction process in the microwave-intensified reactor for hydrolyzation and the composition of water, protein and oil in raw material [5]. The $\mathrm{FPH}$ solution from the middle stream was further spray-dried to FPH powder. FPH powder was defined as the main product/revenue; fish oil and FPCP left-over were defined as co-products/revenue. Thus the waste treatment in this process design is assumed to be zero.

\section{Simulation of the microwave-intensified chemical process}

The conceptual industrial process designed for the microwaveintensified chemical process line is demonstrated in Figure 2. The only difference between Figures 2 and 1 is that instead of adding Flavourzyme into the microwave-intensified reactor, $\mathrm{NaOH}$ was added [14].

All other process parameters related to the simulation of the microwave-intensified chemical process were the same as those used in the simulation of the microwave-intensified enzymatic process. The only difference is that the protein recovery in the simulation of the microwave-intensified chemical process increased to $98.05 \%$, based on the laboratory data using $\mathrm{pH} 14$ in our previous study [5].

\section{Process simulation scenarios}

The process simulations in this study were made based on several scenarios including: the variations in FPH production yield per batch, FPCP purchase cost and the FPH selling price.

\section{Summary of the experimental data used in the simulations}

The experimental data used in the process simulations is summarized in Table 1. The economic feasibility analysis of FPH industrial production was conducted based on the simulation data described above. An Economic Evaluation Report was generated for each simulation scenario by Superpro Designer (version 8.0). This study has compared key performance of each process design, including the production yield per batch, the amount of starting material per batch, amount of FPCP used annually, total capital investment, the operation cost, total annual revenue and the most importantly, the investment payback time [15-17].

\section{Results and Discussions}

\section{Effect of the production yield per batch on simulations}

In the initial simulations, the FPCP purchase cost was set at the highest cost of USD $3 / \mathrm{kg}$, as expected by the seafood processing

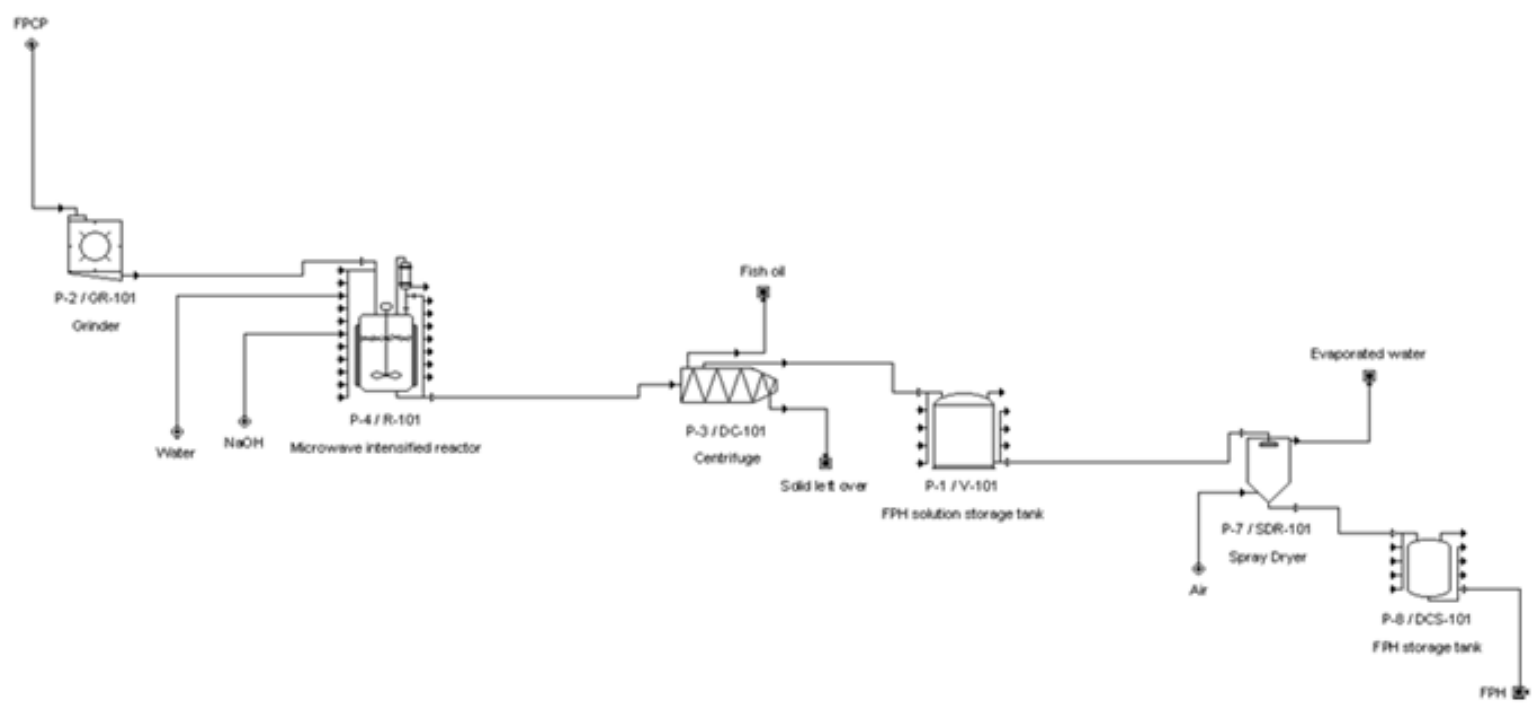

Figure 2: The flow sheet for the microwave-intensified chemical process to produce FPH 
industry, the selling price of FPH was set at USD 20/kg, the market price of the reference product (egg white powder) mentioned before. The effect of the production yield per batch on the microwave-intensified enzymatic process and the microwave-intensified chemical process are shown in Tables 2 and 3, respectively [18].

Based on current available amounts of FPCP, there is no positive payback time and return on investment that could be achieved for the microwave-intensified enzymatic process regardless the production yield per batch (Table 2), due to the high operation cost. This result is important as it proves for the first time that the enzymatic hydrolysis of FPCP is not economically feasible when scaled up as stated in other studies $[4,7]$.

The economic significance of the increase of protein recovery from $62.45 \%$ of the microwave-intensified enzymatic process to $98.05 \%$ in the microwave-intensified chemical process is demonstrated in Table 3. The highest annual production yield of FPH increased from 463 tons using the microwave-intensified enzymatic process (Table 2) to 740.8 tons using the microwave-intensified chemical process (Table $3)$. In comparison, the annual operation cost was significantly reduced from USD 14.78 million (Table 2) to USD 10.28 million (Table 3). These results indicate that the microwave-intensified chemical process is more profitable to be scaled up than the microwave-intensified enzymatic process [19-21].

Indeed, a positive return on investment of $3.01 \%$ and $5.20 \%$ can be achieved with the annual production yields of 648.2 tonnes and 740.8 tonnes, respectively. The payback time for these two annual production yields are 292.29 and 17.62 years, respectively (Table 3 ). However these payback times are too lengthy to be acceptable by the food industry. Therefore, the operation cost needs to be further reduced in order to shorten the payback time to the acceptable period of around 2 years. As a result, operation cost is expected to be further reduced.

The breakdown of the annual operation cost data of the microwaveintensified enzymatic process and the microwave-intensified chemical process, based on the highest production yield per batch in Tables 2 and 3, respectively, is presented in (Table 4).

The largest operation costs for both processes was the raw materials cost (about USD 11.4 million), which account for $78.03 \%$ for the microwave-intensified enzymatic process and $76.98 \%$ for microwaveintensified chemical process. Given this fact, it is important to reduce the purchase cost of raw materials in order to shorten the investment payback time and return on investment [22,23].

The further breakdown of the purchase cost of raw materials for the microwave-intensified enzymatic process and the microwaveintensified chemical process in Table 4 is presented in Tables 5 and 6 , respectively. Given the fact that $98.55 \%$ and $99.45 \%$ of raw material cost is on FPCP for the microwave-intensified enzymatic process and the microwave-intensified chemical process, respectively, it is important to look at the contribution of the cost of FPCP to the investment payback time [24].

Many previous studies concluded that the enzymatic process may not be cost-effective due to the high cost of the enzyme. It is important to address here that this conclusion is based on the laboratory production without considering the contribution of other factors, such as the purchase cost of FPCP, labor cost and facility cost, which have to be considered for any industrial production. Results in Table 7 clearly indicate that this laboratory-based conclusion does not apply to the industrial level production. As mentioned before, the seafood industry proposed the selling price of FPCP as USD $3 / \mathrm{kg}$ for the $\mathrm{FPH}$ production on large scale, therefore it is highly unlike that FPCP can be obtained cost-free for industrial production, even if the production was to be carried out by the same processor [25]. Table 7 shows that when the purchase cost of FPCP changed from USD 3/kg to USD $1 / \mathrm{kg}$, the purchase cost of FPCP in raw material cost changed from $98.55 \%$ to $96.03 \%$, and the percentage of raw materials cost in the operation cost is still more than $50 \%$ (78.03\% to $54.88 \%)$, whereas the cost of Flavourzyme only accounts for $0.91 \%$ to $2.65 \%$ of the cost of raw materials. Indeed, the cost of Flavourzyme is $66.61 \%$ of the cost of raw materials if FPCP can be received for free. However, given the consideration of other industry processing factors, such as labor cost and facility cost and the cost of raw materials, it only accounts for $4.61 \%$ of the operation cost- therefore the cost of Flavourzyme is also not significant in industrial scale production $[26,27]$. Table 7 presented the other factors, such as the purchase cost of FPCP, rather than the cost of enzymes, that should be paid more attention to in the industrial production of FPH.

\section{Simulations based on the variation of the FPCP purchase cost and FPH selling price}

Table 7 shows the importance of the FPCP purchase cost to the annual cost of raw materials. In all the previous simulation input and results shown in Tables 1-6, the FPCP purchase cost was set at USD $3 / \mathrm{kg}$. Currently the seafood industry offers FPCP for free to produce fertilizer, or pays USD 150 per ton for waste disposal. Given this fact, we have evaluated the potential impact of varying FPCP purchase costs on the payback time and return on investment on the microwaveintensified chemical process (Table 8 ) and the microwave-intensified enzymatic process (Table 9) [28]. It is clear that the investment payback time is very sensitive to the purchase cost of FPCP for both processes. Based on the pre-set FPH selling price of USD 20/kg and reducing the FPCP purchase cost from USD $3 / \mathrm{kg}$ to USD $1 / \mathrm{kg}$, The payback time of the microwave-intensified chemical process changed from 17.63 years to 2.40 years (Table 8 ), from no payback time (N/A) to 3.94 years (Table 9) for the microwave-intensified chemical process and the microwaveintensified enzymatic process, respectively. The corresponding return on investment increased from $5.44 \%$ to $41.73 \%$, and from $-16.64 \%$ to $25.41 \%$ for the microwave-intensified chemical process and the microwave-intensified enzymatic process, respectively. This trend demonstrates the significant influence of FPCP purchase price on the profitability of FPH industrial production. In order to achieve a low purchase cost of FPCP, a profit-sharing agreement between FPH producer and FPCP raw material supplier is important.

Selling price of products is another crucial factor that industry has to consider. In all the previous simulations, the selling price of FPH was assumed at USD $20 / \mathrm{kg}$, based on the market price of the reference product, egg white powder. With the current market trends, it is less likely that the price will drop below USD 20/kg. Therefore we simulated the scenario of increasing the price from USD 20/kg to USD $40 / \mathrm{kg}$ to understand the sensitivity of investment payback time, and only simulated one scenario of reducing the price from USD 20/kg to USD $10 / \mathrm{kg}$. The potential impact of varying FPH selling price on investment payback time and return on investment for the microwave-intensified chemical process and the microwave-intensified enzymatic process is evaluated in Tables 8 and 9, respectively. The investment payback time and return on investment are also very sensitive to the selling price of FPH for both processes. Based on the purchase cost of FPCP of USD $3 / \mathrm{kg}$, the payback time for the microwave-intensified chemical process changed from no payback time (N/A) to 1.40 years (Table 8 ), 
Citation: Shan He, Christopher MM, Franco, Zhang W (2015) Economic Feasibility Analysis of the Industrial Production of Fish Protein Hydrolysates using Conceptual Process Simulation Software. J Bioprocess Biotech 5: 191 doi: 10.4172/2155-9821.1000191

Page 5 of 8

\begin{tabular}{|c|c|c|}
\hline & Microwave-intensified enzymatic process & Microwave-intensified chemical process \\
\hline Protein recovery & $62.45 \%$ & $98.05 \%$ \\
\hline Processing time & $20 \mathrm{~min}$ & $20 \mathrm{~min}$ \\
\hline Processing pH & 6.5 (normal pH without adjustment) & 14 (adjusted using $\mathrm{NaOH}$ ) \\
\hline E/S ratio & $0.5 \%$ & ---- \\
\hline Annual processing time & 7200 hours & 7200 hours \\
\hline $\begin{array}{l}\text { Annual available raw material (YTK head and } \\
\text { frame) }\end{array}$ & 3,900 tons & 3,900 tons \\
\hline Cost of FPCP & USD 3 /kg maximum & USD 3 /kg maximum \\
\hline Equipment annual depreciation & $10 \%$ & $10 \%$ \\
\hline Labor cost & USD $69 / \mathrm{hr}$ & USD 69/hr \\
\hline Cost of enzyme (Flavourzyme) & USD $56 / \mathrm{kg}$ & ---- \\
\hline Cost of $\mathrm{NaOH}$ & ---- & USD $0.2 / \mathrm{kg}$ \\
\hline Price of FPH & USD 20/kg & USD 20/kg \\
\hline Price of crude fish oil & USD 1.2/kg & USD 1.2/kg \\
\hline Price of fish meal & USD $1.7 / \mathrm{kg}$ & USD $1.7 / \mathrm{kg}$ \\
\hline
\end{tabular}

Table 1: Summary of data used for process simulation

\begin{tabular}{|c|c|c|c|c|c|c|c|}
\hline $\begin{array}{c}\text { FPH Production } \\
\text { yield /batch (kg) }\end{array}$ & $\begin{array}{c}\text { Annual FPH } \\
\text { production yield } \\
\text { (ton) }\end{array}$ & $\begin{array}{c}\text { Starting } \\
\text { materials FPCP } \\
\text { batch (ton) }\end{array}$ & $\begin{array}{c}\text { Annual used } \\
\text { FPCP materials } \\
\text { (ton) }\end{array}$ & $\begin{array}{c}\text { Total capital } \\
\text { investment } \\
\text { (million USD) }\end{array}$ & $\begin{array}{c}\text { Operation cost/ } \\
\text { year (million } \\
\text { USD) }\end{array}$ & $\begin{array}{c}\text { Total revenues } \\
\text { year (million } \\
\text { USD ) } \\
\text { (main } \\
\text { revenue + co } \\
\text { revenue }\end{array}$ & $\begin{array}{c}\text { Payback time } \\
\text { (Year) }\end{array}$ \\
\hline 100 & 92.6 & 0.9 & 755 & 10.96 & 5.07 & $2.50(1.85+0.64)$ \\
\hline Return on \\
investment
\end{tabular}

"Simulations were based on the purchase cost of FPCP at USD 3/kg, selling price of FPH at USD 20/kg and the maximum annual available FPCP of 3,900 tons *N/A: Not applicable

Table 2: Economic feasibility analysis* of FPH industrial production using the microwave-intensified enzymatic process at different production scale

\begin{tabular}{|c|c|c|c|c|c|c|c|c|}
\hline $\begin{array}{l}\text { FPH Production } \\
\text { yield /batch }(\mathbf{k g})\end{array}$ & $\begin{array}{c}\text { Annual FPH } \\
\text { production yield } \\
\text { (ton) }\end{array}$ & $\begin{array}{c}\text { Starting } \\
\text { materials FPCP / } \\
\text { batch (ton) }\end{array}$ & $\begin{array}{l}\text { Annual used } \\
\text { FPCP materials } \\
\text { (ton) }\end{array}$ & $\begin{array}{c}\text { Total capital } \\
\text { investment } \\
\text { (million USD) }\end{array}$ & $\begin{array}{l}\text { Operation cost/ } \\
\text { year (million } \\
\text { USD) }\end{array}$ & $\begin{array}{c}\text { Total revenues } \\
\text { year (million USD ) } \\
\text { (main revenue + co } \\
\text { revenue }\end{array}$ & Payback time & $\begin{array}{c}\text { Return on } \\
\text { investment }\end{array}$ \\
\hline 100 & 92.6 & 0.9 & 755 & 10.96 & 5.07 & $2.50(1.85+0.64)$ & $N / A^{* *}$ & $-22.42 \%$ \\
\hline 200 & 185. 2 & 1.8 & 1511 & 11.79 & 7.54 & $5.00(3.71+1.29)$ & $\mathrm{N} / \mathrm{A}$ & $-20.81 \%$ \\
\hline 300 & 277.8 & 2.7 & 2267 & 12.31 & 9.95 & $7.51(5.56+1.94)$ & $\mathrm{N} / \mathrm{A}$ & $-19.29 \%$ \\
\hline 400 & 370.4 & 3.6 & 3022 & 12.94 & 12.38 & $10.01(7.42+.59)$ & $\mathrm{N} / \mathrm{A}$ & $-17.86 \%$ \\
\hline 500 & 463 & 4.5 & 3778 & 13.38 & 14.78 & $12.51(9.28+3.23)$ & N/A & $-16.64 \%$ \\
\hline 600 & 555.6 & 3.4 & 2858 & 12.83 & 11.8 & $11.48(10.58+0.98)$ & $\mathrm{N} / \mathrm{A}$ & $-0.74 \%$ \\
\hline 700 & 648.2 & 3.96 & 3335 & 13.16 & 13.32 & $13.39(12.34+1.05)$ & 292.29 & $3.01 \%$ \\
\hline 800 & 740.8 & 4.53 & 3811 & 13.48 & 14.91 & $15.31(14.10+1.20)$ & 17.62 & $5.20 \%$ \\
\hline
\end{tabular}

*Simulations were based on the purchase cost of FPCP at USD $3 / \mathrm{kg}$, selling price of FPH at USD $20 / \mathrm{kg}$ and the maximum annual available FPCP of 3,900 tons "N/A: Not applicable

Table 3: Economic feasibility analysis* of FPH industrial production using the microwave-intensified chemical process at different production scale

from no payback time (N/A) to 3.15 years (Table 9) for the microwaveintensified chemical process and the microwave-intensified enzymatic process, respectively. The return on investment also increased from $-42.77 \%$ to $71.53 \%$, from $-51.16 \%$ to $31.70 \%$ for the microwaveintensified chemical process and the microwave-intensified enzymatic process, respectively. A similar trend is also shown in different rows representing the different purchase cost of FPCP in Tables 8 and 9. The sensitivity of the investment payback time and return on investment to the selling prices of FPH shows the importance of expanding market demand of FPH in order to increase its market price [29-31].

As mentioned before, the food industry expects any investment to be paid back within 2 years. It can be seen in Tables 8 and 9 that this expectation can be achieved by a combination of factors such as the FPCP purchase cost and the FPH selling price. A FPH selling price of above USD $30 / \mathrm{kg}$ is able to secure an investment payback time of around 2 years for the microwave-intensified chemical process (Table 8). With the combined impact of the FPCP purchase cost from USD $1 / \mathrm{kg}$ to USD $3 / \mathrm{kg}$, and the FPH selling price from USD $20 / \mathrm{kg}$ to USD $40 / \mathrm{kg}$, the lowest investment payback time with the highest return on investment for the microwave-intensified chemical process and the microwave-intensified enzymatic process can be reached in 0.89 years (111.78\%) and 1.44 years (69.49\%), respectively [30].

The simulations in Tables 8 and 9 show the potential profitability of the industrial production of FPH using FPCP as the raw material. In order to maximize the profit of the FPH business, the strategies to reduce the FPCP purchase cost and increase the FPH selling price have to be seriously considered, rather than the cost of enzymes, which has been emphasized in previous studies based on laboratory data without considering the processing parameters that are important for industrial production. 
Citation: Shan He, Christopher MM, Franco, Zhang W (2015) Economic Feasibility Analysis of the Industrial Production of Fish Protein Hydrolysates using Conceptual Process Simulation Software. J Bioprocess Biotech 5: 191 doi: 10.4172/2155-9821.1000191

Page 6 of 8

\begin{tabular}{|c|c|c|c|c|}
\hline \multirow[t]{2}{*}{ Cost item } & \multicolumn{2}{|c|}{ USD \$ } & \multicolumn{2}{|c|}{$\%$} \\
\hline & MIEP & & MIEP & MICP \\
\hline Raw materials & $11,502,243$ & $11,497,644$ & 78.03 & 76.98 \\
\hline Facility-Dependent & 774,000 & $2,194,000$ & 14.03 & 14.77 \\
\hline Labor & $2,116,000$ & 746,000 & 5.25 & 5.02 \\
\hline Utilities & 177,000 & 202,000 & 1.20 & 1.36 \\
\hline Consumables & 102,000 & 165,000 & 0.69 & 1.11 \\
\hline Laboratory/QC/QA & 116,000 & 112,000 & 0.79 & 0.75 \\
\hline Waste treatment & 0 & 0 & 0 & 0 \\
\hline Transportation & 0 & 0 & 0 & 0 \\
\hline Miscellaneous & 0 & 0 & 0 & 0 \\
\hline Advertising/Selling & 0 & 0 & 0 & 0 \\
\hline Running Royalties & 0 & 0 & 0 & 0 \\
\hline Failed Product Disposal & 0 & 0 & 0 & 0 \\
\hline Total & $14,787,000$ & $14,916,644$ & 100.00 & 100.00 \\
\hline
\end{tabular}

MIEP: Microwave-Intensified Enzymatic Process

MICP: Microwave-Intensified Chemical Process

"Simulations were based on the purchase cost of FPCP at USD 3/kg, selling price of FPH at USD 20/kg and the maximum annual available FPCP of 3,900 tons

Table 4: Annual operation cost of the microwave-intensified enzymatic process and microwave-intensified chemical process

\begin{tabular}{|c|c|c|c|c|}
\hline Raw material & $\begin{array}{c}\text { Unit cost } \\
\text { (USD/kg) }\end{array}$ & $\begin{array}{c}\text { Annual amount } \\
\text { (kg) }\end{array}$ & $\begin{array}{c}\text { Annual cost } \\
\text { (USD) }\end{array}$ \\
\hline FPCP & 3.00 & $3,778,502$ & $11,355,505$ \\
\hline Water & 0.006 & $10,435,138$ & 62,611 \\
\hline Flavourzyme & 50.00 & 2,003 & 104,127 \\
\hline Air & 0 & 0 & 0 & 0.54 \\
\hline Total & & & $11,502,243$ \\
\hline
\end{tabular}

Table 5: Raw material cost of FPH industrial production using the microwave-intensified enzymatic process with the production yield per batch of $500 \mathrm{~kg}$

\begin{tabular}{|c|c|c|c|c|}
\hline Raw material & $\begin{array}{c}\text { Unit Cost } \\
\text { (USD/kg) }\end{array}$ & $\begin{array}{c}\text { Annual Amount } \\
\text { (kg) }\end{array}$ & $\begin{array}{c}\text { Annual Cost } \\
\text { (USD) }\end{array}$ & $11,434,431$ \\
\hline FPCP & 3.00 & $3,811,477$ & 62,793 \\
\hline Water & 0.006 & $10,465,429$ & 420 \\
\hline NaOH & 0.2 & 2,101 & 0 \\
\hline Air & 0 & 0 & $0.55 \%$ \\
\hline Total & & & 0 \\
\hline
\end{tabular}

Table 6: Raw material cost of FPH industrial production using the microwave-intensified chemical process with the production yield per batch of $800 \mathrm{~kg}$

\begin{tabular}{|c|c|c|c|c|c|}
\hline $\begin{array}{l}\text { FPCP } \\
\text { unit cost } \\
\text { (USD/kg) }\end{array}$ & $\begin{array}{l}\text { Annual cost } \\
\text { of FPCP } \\
\text { (USD) }\end{array}$ & $\begin{array}{c}\text { Annual cost of } \\
\text { enzymes } \\
\text { (USD) }\end{array}$ & $\begin{array}{l}\text { Percentage of FPCP cost } \\
\text { in } \\
\text { raw materials cost }\end{array}$ & $\begin{array}{l}\text { Percentage of enzyme cost in } \\
\text { raw materials cost }\end{array}$ & $\begin{array}{c}\text { Percentage of raw materials cost in } \\
\text { operation cost }\end{array}$ \\
\hline 3.00 & $11,355,431$ & 104,127 & $98.55 \%$ & $0.91 \%$ & $78.03 \%$ \\
\hline 2.00 & $7,557,003$ & 104,127 & $97.97 \%$ & $1.35 \%$ & $70.45 \%$ \\
\hline 1.00 & $3,778,502$ & 104,127 & $96.03 \%$ & $2.65 \%$ & $54.88 \%$ \\
\hline 0 & 0 & 104,127 & $0 \%$ & $66.61 \%$ & $4.61 \%$ \\
\hline
\end{tabular}

Table 7: Percentage of purchase cost of FPCP enzyme in raw materials cost and percentage of raw material cost in total operation cost, with different purchase cost of FPCP

\begin{tabular}{|c|c|c|c|c|c|c|}
\hline $\begin{array}{l}\text { FPH price (USD /kg) } \\
\text { FPCP purchase cost } \\
\text { (USD /kg) }\end{array}$ & 10 & 20 & 25 & 30 & 35 & 40 \\
\hline 3 & $\begin{array}{c}\mathrm{N} / \mathrm{A}^{*} \\
(-42.7 \%)\end{array}$ & $\begin{array}{c}17.63 \\
(5.4 \%)\end{array}$ & $\begin{array}{c}4.55 \\
(21.9 \%)\end{array}$ & $\begin{array}{c}2.60 \\
(38.4 \%)\end{array}$ & $\begin{array}{c}1.82 \\
(55.0 \%)\end{array}$ & $\begin{array}{c}1.40 \\
(71.5 \%)\end{array}$ \\
\hline 2 & $\begin{array}{c}\mathrm{N} / \mathrm{A} \\
(-18.6 \%)\end{array}$ & $\begin{array}{c}4.36 \\
(23.0 \%)\end{array}$ & $\begin{array}{c}2.50 \\
(40.0 \%)\end{array}$ & $\begin{array}{c}1.75 \\
(57.0 \%)\end{array}$ & $\begin{array}{c}1.35 \\
(74.0 \%)\end{array}$ & $\begin{array}{c}1.10 \\
(91.0 \%)\end{array}$ \\
\hline $\begin{array}{l}1 \\
0\end{array}$ & $\begin{array}{c}24.61 \\
(4.0 \%) \\
4.97 \\
(20.1 \%)\end{array}$ & $\begin{array}{c}2.40 \\
(41.7 \%) \\
1.63 \\
(61.5 \%)\end{array}$ & $\begin{array}{c}1.69 \\
(59.2 \%) \\
1.26 \\
(79.6 \%)\end{array}$ & $\begin{array}{c}1.30 \\
(76.7 \%) \\
1.02 \\
(97.6 \%)\end{array}$ & $\begin{array}{c}1.06 \\
(94.2 \%) \\
0.86 \\
(115.7 \%)\end{array}$ & $\begin{array}{c}0.89 \\
(111.7 \%) \\
0.75 \\
(133.7 \%)\end{array}$ \\
\hline
\end{tabular}

"N/A: not available, which means no payback time

Table 8: Impact of the FPCP purchase cost and FPH price on investment payback time and return on investment (in bracket), based on the microwave-intensified chemical process with the production yield of $800 \mathrm{~kg}$ per batch 
Citation: Shan He, Christopher MM, Franco, Zhang W (2015) Economic Feasibility Analysis of the Industrial Production of Fish Protein Hydrolysates using Conceptual Process Simulation Software. J Bioprocess Biotech 5: 191 doi: 10.4172/2155-9821.1000191

Page 7 of 8

\begin{tabular}{|c|c|c|c|c|c|c|}
\hline $\begin{array}{c}\text { FPH price } \\
\text { (USD /kg) FPCP } \\
\text { purchase cost } \\
\text { (USD /kg) }\end{array}$ & 10 & 20 & 25 & 30 & 35 & 40 \\
\hline 3 & $\begin{array}{c}\mathrm{N} / \mathrm{A}^{*} \\
(-51.1 \%)\end{array}$ & $\begin{array}{c}\mathrm{N} / \mathrm{A} \\
(-16.6 \%)\end{array}$ & $\begin{array}{l}199.52 \\
(0.5 \%)\end{array}$ & $\begin{array}{c}9.17 \\
(10.9 \%)\end{array}$ & $\begin{array}{c}4.70 \\
(21.3 \%)\end{array}$ & $\begin{array}{c}3.15 \\
(31.7 \%)\end{array}$ \\
\hline 2 & $\begin{array}{c}\mathrm{N} / \mathrm{A} \\
(-23.6 \%)\end{array}$ & $\begin{array}{c}13.81 \\
(7.2 \%)\end{array}$ & $\begin{array}{c}5.57 \\
(17.9 \%)\end{array}$ & $\begin{array}{c}3.49 \\
(28.6 \%)\end{array}$ & $\begin{array}{c}2.54 \\
(39.3 \%)\end{array}$ & $\begin{array}{c}2.00 \\
(50.0 \%)\end{array}$ \\
\hline $\begin{array}{l}1 \\
0\end{array}$ & $\begin{array}{c}29.70 \\
(3.3 \%) \\
4.55 \\
(21.9 \%)\end{array}$ & $\begin{array}{c}3.94 \\
(25.4 \%) \\
2.24 \\
(44.7 \%)\end{array}$ & $\begin{array}{c}2.74 \\
(36.4 \%) \\
1.78 \\
(56.0 \%)\end{array}$ & $\begin{array}{c}2.11 \\
(47.4 \%) \\
1.48 \\
(67.4 \%)\end{array}$ & $\begin{array}{c}1.71 \\
(58.4 \%) \\
1.27 \\
(78.7 \%)\end{array}$ & $\begin{array}{c}1.44 \\
(69.4 \%) \\
1.11 \\
(90.1 \%)\end{array}$ \\
\hline
\end{tabular}

"N/A: not available, which means no payback time.

Table 9: Impact of the FPCP purchase cost and FPH selling price on investment payback time and return on investment (in bracket), based on the microwave-intensified enzymatic process with the production yield of $500 \mathrm{~kg}$ per batch

\section{Conclusions}

The economic feasibility of scaling up FPH production at the industrial scale was simulated using Superpro Designer (version 8.0), based on a maximum of 3,900 tonnes FPCP raw material available annually in South Australia. The simulations were based on the processing parameters of the microwave-intensified enzymatic process and the microwave-intensified chemical process developed as demonstrated in our previous studies. They demonstrated that the microwave-intensified chemical process is economically more feasible than the microwave-intensified enzymatic process to be scaled up for industry production.

In order to find key processing parameters to carry out simulations with the aim of shortening the investment payback time, analysis of the breakdown of operation cost and raw material cost was carried. The outcome indicated that the purchase cost of FPCP is the major factor that affects the industrial operation cost, rather than the cost of the enzyme, which has been addressed in previous studies without considering processing parameters of industrial production. The potential impact of the purchase cost of FPCP and the selling price of FPH on the investment payback time and return on investment showed that the expected investment payback time of around 2 years from food industry can be potentially achieved, by the combined contribution of the purchase cost of FPCP (from USD $3 / \mathrm{kg}$ to USD $1 / \mathrm{kg}$ ) and the selling price of FPH (from USD 20/kg to USD 40/kg). The simulation in this study clearly demonstrated the commercial feasibility and profitability of the two processes: the microwave-intensified enzymatic process and the microwave-intensified chemical process, to produce FPH on an industrial scale.

\section{Acknowledgements}

The authors are grateful for the Australian Seafood Cooperative Research Centre and Simplot Australia for funding support and for awarding a Postgraduate Scholarship to Shan $\mathrm{He}$, and their advice and supply of Yellowtail Kingfish.

\section{References}

1. He S, Franco C, Zhang W (2013) Functions, applications and production of protein hydrolysates from fish processing co-products (FPCP). Food Research International 50: 289-297.

2. Diniz FM, Martin AM (1997) Effects of the extent of enzymatic hydrolysis on functional properties of shark protein hydrolysate. LWT - Food Science and Technology 30: 266-272.

3. Gbogouri GA, Linder M, Fanni J, Parmentier M (2004) Influence of hydrolysis degree on the functional properties of salmon byproducts hydrolysates. Journal of Food Science 69: C615-C622.

4. Kristinsson HG, Rasco BA (2000) Fish protein hydrolysates: production, biochemical, and functional properties. Crit Rev Food Sci Nutr 40: 43-81.
5. He S, Franco C, Zhang W (2012) Process optimisation and physicochemical characterisation of enzymatic hydrolysates of proteins from co-products of Atlantic Salmon (Salmo salar) and Yellowtail Kingfish (Seriola lalandi). International Journal of Food Science and Technology 47: 2397-2404.

6. Saska M (2008) Modeling boiling house operations with Superpro Designer: effects of final molasses recycle and double magma boiling. The Sugar Journal $1-13$.

7. Liceaga-Gesualdo AM, Li-Chan ECY (1999) Functional properties of fish protein hydrolysate from herring (Clupea harengus). Journal of Food Science 64: 1000-1004.

8. Albert S, Mittal GS (2002) Comparative evaluation of edible coatings to reduce fat uptake in a deep fried cereal products. Food Research International 35 445-448.

9. Aguilera JM, Gloria H (1997) Determination of oil in fried potato products by differential scanning calorimetry. J Agric Food Chem 45: 781-785.

10. Sharpless KE, Gill LM (2000) Value assignment of nutrient concentrations in five standard reference materials and six reference materials. J AOAC Int 83: 413-423.

11. Association of Analytical Communities (2002) Histamine in seafood Fluorometric method. Ch 35, 16-17.

12. Corsaro A, Chiacchio U, Pistara V, Romeo G (2008) Microwave-assisted Chemistry of Carbohydrates. Microwaves in Organic Synthesis. Second Edition, Wiley-VCH Verlag GmbH: 579-614.

13. Foh MBK, Wenshui X, Amadou I, Jiang Q (2011) Influence of pH shift on functional properties of protein isolated of Tilapia (Oreochromis niloticus) muscles and of soy protein isolate. Food Bioprocess Technol 5: 2192-2200.

14. Garcia MA, Ferrero C, Bertola N, Martino M, Zaritzky N (2002) Edible coating from cellulose derivatives to reduce oil uptake in fried products. Innovative Food Science and Emerging Technologies 3: 391-397.

15. Gildberg A, Bogwald J, Johansen A, Stenberg E (1996) Isolation of acid peptide fractions from fish protein hydrolysates with strong stimulatory effect on Atlantic salmon (Salmon salar) head kidney leucocytes. Comparative Biochemistry and Physiology Part B: Biochemistry and Molecular Biology 114: 97-101.

16. Shan H, Gorczyca E, Kasapis S, Lopata A (2010) Optimization of hydrogenperoxide washing of common carp kamaboko using response surface methodology. LWT-Food Science and Technology 43: 765-770.

17. He S, Franco C, Zhang W (2011) Characterisation of processing wastes of Atlantic Salmon (Salmo salar) and Yellowtail Kingfish (Seriola lalandi) harvested in Australia. International Journal of Food Science and Technology 46: 1898-1904.

18. Ikem A, Egiebor NO (2005) Assessment of trace elements in canned fishes (mackerel, tuna, salmon, sardines and herrings) marketed in Georgia and Alabama (United States of America). Journal of Food Composition and Analysis 18: 771-787.

19. Izquierdo FJ, Penas E, Baeza ML, Gomez R (2008) Effects of combined microwave and enzymatic treatments on the hydrolysis and immune reactivity of dairy whey proteins. International Dairy Journal 18: 918-922.

20. Lee JS, Kim BK, Kim KH, Park DJ (2008) Preparation of low-fat uptake doughnut by dry particle coating technique. J Food Sci 73: E137-142. 
Citation: Shan He, Christopher MM, Franco, Zhang W (2015) Economic Feasibility Analysis of the Industrial Production of Fish Protein Hydrolysates using Conceptual Process Simulation Software. J Bioprocess Biotech 5: 191 doi: 10.4172/2155-9821.1000191

Page 8 of 8

21. Makinson JH, Greenfield $\mathrm{H}$, Wong ML, Wills RBH (1987) Fat uptake during deep fat frying of coated and uncoated foods. Journal of Food Composition and Analysis 1: 93-101.

22. Mellema M (2003) Mechanism and reduction of fat uptake in deep-fat fried foods. Trends in Food Science \& Technology 14: 364-373.

23. Ooshima H, Aso K, Harano Y, Yamamoto T (1984) Microwave treatment of cellulosic materials for their enzymatic hydrolysis. Biotechnology Letters 6 : 289-294.

24. Pedreschi F, Moyano P (2005) Oil uptake and texture development in fried potato slices. Journal of Food Engineering 70: 557-563.

25. Pinthus EJ, Weinberg $P$, Saguy IS (1995) Oil uptake in deep fat frying as affected by porosity. Journal of Food Science 60: 767-769.

26. Roy I, Mondal K, Gupta MN (2003) Accelerating enzymatic hydrolysis of chitin by microwave pretreatment. Biotechnol Prog 19: 1648-1653.
27. Slizyte R, Dauksas E, Falch E, Storro I, Rustad T (2005) Characteristics of protein fractions generated from hydrolysed cod (Gadus morhua) by-products. Process Biochemistry 40: 2021-2033.

28. Smith LM, Clifford AJ, Creveling RK, Hamblin CL (1985) Lipid content and fatty acid profiles of various deep fat fried foods. Journal of the American Oi Chemists Society 62: 996-999.

29. Southern CR, Chen XD, Farid MM, Howard B, Eyres L (2000) Determining internal oil uptake and water content of fried thin potato crisps. Food and Bioproducts Processing 78: 119-125.

30. United States Environmental Protection Agency (USEPA) (1996) Method $6010 \mathrm{~b}$ and Method 6020

31. Wasswa J, Tang J, Gu X, Yuan X (2007) Influence of the extent of enzymatic hydrolysis on the functional properties of protein hydrolysate from grass carp (Ctenopharyngodon idella) skin. Food Chemistry 104: 1698-1704. 